Tasharruf: Journal Economics and Business of Islam Vol. 4, No. 2 (2019): 92-109

Website: http://journal.iain-manado.ac.id/index.php/TJEBI

ISSN 2528-0325 (online) ISSN 2528-0317 (print)

\title{
PENGARUH MOTIVASI TERHADAP PRODUKTIVITAS KERJA KARYAWAN PT. TELKOM TbK CABANG MAKASSAR
}

\author{
Nurnaningsih \\ Akademi Sekretari dan Manajemen Indonesia (Asmi Publik) \\ Email: nurnaningsihsyarif84@gmail.com \\ Ridwan Tabe \\ Institut Agama Islam Negeri (IAIN) Manado \\ Email: ridwantabe@iain-manado.ac.id
}

\begin{abstract}
Effects of Motivation on Work Productivity of PT. Telkom Tbk Employees in Makassar Branch. The purpose of this study is 1) To determine the effect of employee motivation at PT. Makassar Branch Telkom, 2) To find out which motivation is more dominant in influencing employee work productivity at PT. Telkom Makassar Branch. Data used in this study are primary and secondary data. Population in this study are all employees who work at PT. Telkom Tbk Makassar Branch, amounting to 540 people and samples is 54 people. The analytical method used in this study is multiple linear regression analysis using SPSS. The results showed that: 1) External Motivation in PT. Telkom companies had a significant influence on performance productivity based on employee perceptions, 2) From the results of the analysis, the results showed that external motivation had an effect towards the productivity of the company. While the analysis obtained from internal motivation has an influence on productivity. Thus, the proposed hypothesis is proven, 3) External and internal motivation has a simultaneous effect on employee performance. This is evidenced by the coefficient of determination test, which is equal to $47 \%$ of employee performance is influenced by variations in the two variables used in the study, the remaining 53\% is influenced by other factors, 4) External motivation is more dominantly influencing employee performance this is evidenced by external motivation regression coefficient greater than internal motivation, 5) Internal motivation is the most dominant influence on productivity is good communication between employees and supervisors of internal motivation is the work performance that is owned based on the research conducted.
\end{abstract}

Keywords: Motivation; Productivity; Employees 


\section{PENDAHULUAN}

Suatu perusahaan dalam melaksanakan kegiatannya, baik perusahaan yang bergerak di bidang industry, perdagangan maupun jasa akan berusaha untuk mencapai tujuan yang telah ditetapkan sebelumnya. Satu hal yang penting yaitu bahwa keberhasilan berbagai aktivitas di dalam perusahaan dalam mencapai tujuan bukan hanya tergantung pada pada keunggulan teknologi, dana operasi yang tersedia, sarana ataupun prasarana yang dimiliki, melainkan juga tergantung pada aspek sumber daya manusia. Faktor sumber daya manusia ini merupakan elemen yang harus diperhatikan oleh perusahaan, terutama bila mengingat bahwa era perdagangan bebas akan segera dimulai, dimana iklim kompetisi yang dihadapi akan sangat berbeda. Hal ini memaksa setiap perusahaan harus dapat bekerja dengan lebih efisien, efektif dan produktif. Tingkat kompetisi yang tinggi akan memacu tiap perusahaan untuk dapat mempertahankan kelangsungan hidupnya dengan memberikan perhatian pada aspek sumber daya manusia. Jadi manusia dapat dipandang sebagai faktor penentu karena ditangan manusialah segala inovasi akan direalisir dalam upaya mewujudkan tujuan perusahaan.

Seperti mitra kerja yang diadakan PT. Telkom dengan membuat perjanjian kerja sama dengan PT. Ovis Internasional dalam menerbitkan community "Priority Care" yang ditunjukkan kepada para pelanggan Telkom, jaminan layanan khusus yang meliputi layanan pasang baru telepon, gangguan, pengaduan buku isolir dan pengaduan tagihan. Dari kerja sama di atas dapat kita liat karyawan akan bekerja lebih maksimal untuk bisa menjalankan kerja sama ini serta bisa melayani pelanggan dengan baik. Maka dari itu motivasi dalam kegiatan ini sangat berpengaruh untuk memaksimalkan kinerja karyawan PT. Telkom

Untuk mendapatkan sumber daya manusia yang diharapkan oleh organisasi agar memberikan andil positif terhadap semua kegiatan perusahaan dalam mencapai tujuannya, setiap karyawan diharapkan memiliki motivasi kerja yang tinggi sehingga nantinya akan meningkatkan produktivitas kerja yang tinggi. Motivasi merupakan hal yang sangat penting untuk diperhatikan oleh pihak manajemen bila mereka menginginkan setiap karyawan dapat memberikan kontribusi positif terhadap pencapaian tujuan perusahaan. Karena dengan motivasi, seorang karyawan akan memiliki semangat yang tinggi dalam melaksanakan tugas yang dibebankan kepadanya. Tanpa motivasi, seorang karyawan tidak dapat memenuhi tugasnya sesuai standar atau bahkan melampaui standar karena apa yang menjadi motif dan motivasinya dalam bekerja tidak terpenuhi. Sekalipun seorang karyawan memiliki kemampuan operasional yang baik bila tidak memiliki motivasi dalam bekerja, hasil akhir dari pekerjaannya tidak akan memuaskan. Menyadari betapa pentingnya motivasi dalam upaya meningkatkan produktivitas kerja karyawan ini. Maka PT. Telkom Tbk, dengan segala keterbatasan yang dimiliki mencoba untuk melaksanakan program tersebut.

Terkait mengenai motivasi Reskar pada tahun 2001 melakukan penelitian dan mendapatkan hasil positif mengenai pengaruh motivasi terhadap produktivitas. Semakin termotivasi karyawan dalam melakukan pekerjaan maka produktivitas kerja karyawan tersebut tinggi. Sebaliknya jika karyawan tidak termotivasi dalam suatu pekerjaan maka 
produktivitas kinerja karyawan rendah.

Kesimpulan yang dapat dikutip dari teori Herzberg adalah motivasi karyawan terbagi atas dua jenis yakni Hygiene Factors (Motivasi Eksternal) dan Motivation Factors (Motivasi Internal). Sedangkan Fredrick Taylor mengemukakan motivasi eksternal lebih berpengaruh terhadap produktivitas kerja karyawan dibandingkan motivasi internal.

Untuk memotivasi orang lain, kita dapat memberi penghargaan, menghargai, menciptakan pekerjaan yang lebih menarik, menjadi pendengar yang baik, memberi tantangan, serta menolong tapi tidak melakukan sesuatu bagi orang lain yang sebenarnya dapat dilakukan oleh dirinya sendiri.

Salah satu hal yang dapat dilakukan manajer untuk memotivasi bawahannya adalah dengan memberikan reward. Agar pengaruh reward dapat digunakan secara maksimal, manajer perlu, Menghormati keberagaman dan perbedaan individu, Secara jelas memahami apa yang orang lain inginkan dari suatu pekerjaan dan Mengalokasikan rewards untuk memuaskan kebutuhan individu dan organisasi.

Mengingat pentingnya motivasi, maka wujud perhatian pihak manajemen mengenai masalah motivasi karyawan dalam bekerja ialah melakukan usaha dengan jalan memberi motivasi pada karyawan di perusahaan melalui serangkaian usaha tertentu sesuai dengan kebijakan perusahaan, sehingga motivasi karyawan dalam bekerja akan tetap terjaga. Untuk memotivasi karyawan, pimpinan perusahaan harus mengetahui motif dan motivasi yang diinginkan oleh para karyawan. Satu hal yang harus dipahami bahwa orang mau bekerja karena mereka ingin memenuhi kebutuhannya, baik kebutuhan yang disadari maupun kebutuhan yang tidak disadari, berbentuk materi atau non materi, kebutuhan fisik maupun rohaniah.

Pemberian motivasi ini banyak macamnya seperti pemberian kompensasi yang layak dan adil, pemberian penghargaan dan sebagainya. Hal ini dimaksudkan agar apapun yang menjadi kebutuhan karyawan dapat terpenuhi lalu diharapkan para karyawan dapat berkerja dengan baik dan merasa senang dengan semua tugas yang diembannya. Setelah karyawan merasa senang dengan pekerjaannya, para karyawan akan saling menghargai hak dan kewajiban sesama karyawan sehingga terciptalah suasana kerja yang kondusif, pada akhirnya karyawan dengan bersungguh-sungguh memberikan kemampuan terbaiknya dalam menjalankan tugas dan tanggung jawabnya, dan ini berarti disiplin kerjalah yang akan ditunjukan oleh para karyawan, karena termotivasi dalam melaksanakan tugasnya dalam perusahaan.

\section{KAJIAN TEORI}

\section{Pengertian Motivasi}

Motivasi adalah serangkaian sikap dan nilai-nilai yang mempengaruhi individu untuk mencapai hal yang spesifik sesuai dengan tujuan individu. Sikap dan nilai tersebut merupakan suatu kekuatan untuk mendorong individu bertingkah laku dalam mencapai 
Tasharruf: Journal Economics and Business of Islam Vol. 4, No. 2 (2019): 92-109

Website: http://journal.iain-manado.ac.id/index.php/TJEBI

ISSN 2528-0325 (online) ISSN 2528-0317 (print)

tujuan. Dorongan tersebut terdiri dari dua komponen, yaitu: arah perilaku kerja (kerja untuk mencapai tujuan), dan kekuatan perilaku (sebagai kuat usaha individu dalam bekerja). Motivasi meliputi perasaan unik, pikiran dan pengalaman masa lalu yang merupakan bagian dari hubungan internal dan eksternal perusahaan.

Winardi (2002:1) mengemukakan bahwa "istilah motivasi (motivation) berasal dari perkataan latin yakni movere yang berarti menggerakkan (to move)" Motivasi adalah pemberian daya penggerak yang menciptakan kegairahan kerja seseorang agar mereka mau bekerja dengan segala daya upayanya untuk mencapai kepuasan, Hasibuan (2007: 95). Ishak dan Hendri (2003:12) mengemukakan bahwa "motivasi sebagai suatu hal pokok yang menjadi dorongan setiap motif untuk bekerja".

Menurut Robbins (2008:222) motivasi sebagai proses yang menjelaskan intensitas, arah dan ketekunan seseorang individu untuk mencapai tujuan. Berdasarkan pendapat tersebut dapat disimpulkan bahwa; (1) Motivasi kerja merupakan bagian yang urgen dalam suatu organisasi yang berfungsi alat untuk pencapaian tujuan atau sasaran yang ingin dicapai, (2) Motivasi kerja mengandung dua tujuan utama dalam diri individu yaitu untuk memenuhi kebutuhan atau keinginan pribadi dan tujuan organisasi, dan (3) Motivasi kerja yang diberikan kepada seseorang hanya efektif manakala di dalam diri seseorang itu memiliki kepercayaan atau keyakinan untuk maju dan berhasil dalam organisasi. Pada dasarnya motivasi dapat memacu karyawan untuk bekerja keras sehingga dapat mencapai tujuan mereka. Hal ini akan meningkatkan produktivitas kerja karyawan sehingga berpengaruh pada pencapaian tujuan perusahaan.

Menurut Manalung (1982 : 76) mengatakan "Motivasi berarti sesuatu hal yang menimbulkan dorongan atau keadaan yang menimbulkan dorongan. Jadi motivasi dapat pula diartikan faktor yang mendorong orang untuk bertindak dengan cara tertentu" Manalung (1982:76). Menurut $A s$ 'Ad (1995: 45) mengatakan: "Motivasi seringkali diartikan dengan istilah dorongan. Dorongan atau tenaga tersebut merupakan jiwa dan jasmani untuk berbuat mencapai tujuan, sehingga motivasi merupakan suatu driving force yang menggerakkan manusia untuk bertingkah laku, dan di dalam pebuatannya itu mempunyai tujuan tertentu'.As'Ad (1995:45)

Di dalam perusahaan motivasi berperan sangat penting dalam meningkatkan kinerja karyawan. Tujuan dalam memberikan motivasi kerja terhadap karyawan agar karyawan dapat melaksanakan tugasnya secara efektif dan efisien. Dengan demikian berarti juga mampu memelihara dan meningkatkan moral, semangat dan gairah kerja, karena dirasakan sebagai pekerjaan yang menantang. program dengan cara ini suatu organisasi dapat mendorong berkembangnya motivasi berprestasi dalam suatu perusahaan, yang akan memacu tumbuh dan berkembangnya persaingan sehat antara individu/tim kerja dalam suatu perusahaan. Tetapi dalam individu setiap manusia tidak semua karyawan termotivasi lewat lingkungan kerjanya yang biasa disebut dengan motivasi eksternal, tetapi ada juga karyawan yang termotivasi dari dalam dirinya sendiri (motivasi internal) tanpa ada motivasi khusus yang dia dapatkan dalam lingkungan kerjanya.

Motivasi seseorang dapat dipengaruhi oleh dua faktor yaitu: 
Tasharruf: Journal Economics and Business of Islam Vol. 4, No. 2 (2019): 92-109

Website: http://journal.iain-manado.ac.id/index.php/TJEBI

ISSN 2528-0325 (online) ISSN 2528-0317 (print)

1. Faktor Internal Faktor yang berasal dari dalam diri individu, terdiri atas:

a. Persepsi individu mengenai diri sendiri, seseorang termotivasi atau tidak untuk melakukan sesuatu banyak tergantung pada proses kongnitif berupa persepsi. Persepsi seseorang tentang dirinya sendiri akan mendorong dan mengarahkan perilaku seseorang untuk bertindak.

b. Harga diri dan prestasi, faktor ini mendorong atau mengarahkan individu (memotivasi) untuk berusaha agar menjadi pribadi yang mandiri, kuat, dan memperoleh kebebasan serta mendapatkan status tertentu dalam lingkungan masyarakat, serta dapat mendorong individu untuk berprestasi.

c. Harapan, adanya harapan-harapan akan masa depan. Harapan ini merupakan informasi objektif dari lingkungan yang mempengaruhi sikap dan perasaan subjektif seseorang. Harapan merupakan tujuan dari perilaku. 18Veithzal Rivai dan Ella Jauvani Sagala, Manajemen Sumber Daya Manusia untuk Perusahaan.

d. Kebutuhan, manusia dimotivasi oleh kebutuhan untuk menjadikan dirinya sendiri yang berfungsi secara penuh, sehingga mampu meraih potensinya secara total. Kebutuhan akan mendorong dan mengarahkan seseorang untuk mencari atau menghindari, mengarahkan dan memberi respon terhadap tekanan yang dialaminya.

e. Kepuasan kerja, lebih merupakan suatu dorongan efektif yang muncul dalam diri individu untuk mencapai goal atau tujuan yang diinginkan dari suatu perilaku.

2. Faktor Eksternal Faktor yang berasal dari luar diri individu, terdiri atas:

a. Jenis dan sifat karyawan, dorongan untuk bekerja pada jenis dan sifat karyawan tertentu sesuai dengan objek karyawan yang tersedia akan mengarahkan individu untuk menentukan sikap atau pilihan karyawan yang akan ditekuni. Kondisi ini juga dapat dipengaruhi oleh sejauh mana nilai imbalan yang dimiliki oleh objek karyawan dimaksud.

b. Kelompok kerja dimana individu bergabung, kelompok kerja atau organisasi tempat dimana individu bergabung dapat mendorong atau mengarahkan perilaku individu dalam mencapai suatu tujuan perilaku tertentu.

c. Situasi lingkungan pada umumnya, setiap individu terdorong untuk berhubungan dengan rasa mampunya dalam melakukan interaksi secara efektif dengan lingkungannya.

d. Sistem imbalan yang diterima, imbalan merupakan karakteristik atau kualitas dari objek pemuas yang dibutuhkan oleh seseorang dapat mempengaruhi motivasi atau dapat mengubah arah tingkah laku dari satu objek ke objek lain yang mempunyai nilai imbalan yang lebih besar. Sistem pemberian imbalan dapat mendorong individu untuk berperilaku dalam mencapai tujuan, perilaku dipandang sebagai tujuan, sehingga ketika tujuan tercapai maka akan timbul imbalan. 


\section{Teori-Teori Tentang Motivasi}

\section{Teori Maslow}

Salah satu teori motivasi yang paling banyak diacu adalah teori "Hirarki Kebutuhan" yang dikemukakan oleh Abraham Maslow. Maslow memandang kebutuhan manusia berdasarkan suatu hirarki kebutuhan dari kebutuhan yang paling rendah hingga kebutuhan yang paling tinggi. Kebutuhan pokok manusia yang diidentifikasi Maslow dalam urutan kadar pentingnya adalah sebagai berikut:

a. Kebutuhan Fisiologis (Basic Needs) Misalnya sandang, pangan, papan dan kesejahteraan individu.

b. Kebutuhan akan Rasa Aman (Securely Needs) Dikaitkan dengan kerja maka kebutuhan akan keamanan sewaktu bekerja, perasaan aman yang menyangkut masa depan karyawan

c. Kebutuhan Afiliasi atau Akseptansi (Social Needs)

1) Kebutuhan akan perasaan diterima di mana ia bekerja

2) Kebutuhan akan perasaan dihormati

3) Kebutuhan untuk bisa berprestasi

4) Kebutuhan untuk bisa ikut serta

d. Kebutuhan penghargaan (Esteem Needs) Jenis kebutuhan ini menghasilkan kepuasan seperti kekuasaan, prestasi, status dan keyakinan akan diri sendiri.

e. Kebutuhan Perwujudan Diri (Self-Actualization) Kebutuhan ini merupakan kebutuhan paling tinggi, yakni kebutuhan untuk menjadi orang yang dicita-citakan dan dirasakan mampu mewujudkannya. Koontz, (1990:121).

\section{Teori Dua Faktor Herzberg}

Herzberg mengklaim telah menemukan penjelasan dua faktor motivasi yaitu:

a. Hygiene Factors, yang meliputi gaji, kehidupan pribadi, kualitas supervisi, kondisi kerja, jaminan kerja, hubungan antar pribadi, kebijaksanaan dan administrasi perusahaan. (Eksternal)

b. Motivation Factors, yang dikaitkan dengan isi pekerjaan mencakup keberhasilan, pengakuan, pekerjaan yang menantang, peningkatan dan pertumbuhan dalam pekerjaan. (Internal). Koontz, (1990:123) 


\section{Teori Kebutuhan ERG Alderfer}

Teori ERG Alderfer (Existence, Relatedness, Growth) adalah teori motivasi yang dikemukakan oleh Clayton P. Alderfer. Teori Alderfer menemukan adanya 3 kebutuhan pokok manusia:

a. Existence Needs (Kebutuhan Keadaan) adalah suatu kebutuhan akan tetap bisa hidup sesuai dengan tingkat kebutuhan tingkat rendah dari Maslow yaitu meliputi kebutuhan fisiologis dan kebutuhan akan rasa aman serta Hygiene Factors dari Herzberg.

b. Relatedness Needs (Kebutuhan Berhubungan), mencakup kebutuhan untuk berinteraksi dengan orang lain. Kebutuhan ini sesuai dengan kebutuhan afiliasi dari Maslow dan hygiene factors dari Herzberg.

c. Growth Needs (Kebutuhan Pertumbuhan) adalah kebutuhan yang mendorong seseorang untuk memiliki pengaruh yang kreatif dan produktif terhadap diri sendiri atau lingkungan. Realisasi dari kebutuhan penghargaan dan perwujudan diri dari Maslow dan motivasion factors dari Herzberg. Koontz, (1990:121) 25

4. Teori Motivasi Ekspektansi

Teori motivasi ini diungkapkan oleh Vroom. Vroom mengemukakan bahwa orang-orang akan termotivasi untuk melakukan hal-hal tertentu guna mencapai tujuan apabila mereka yakin bahwa tindakan mereka akan mengarah pada pencapaian tujuan tersebut. Koontz, (1990:123)

\section{Teori Motivasi Klasik}

Teori motivasi ini diungkapkan oleh Frederick Taylor yang menyatakan bahwa pekerja hanya termotivasi semata-mata karena uang. Konsep ini menyatakan bahwa seseorang akan menurun semangat kerjanya bila upah yang diterima dirasa terlalu sedikit atau tidak sebanding dengan pekerjaan yang harus dilakukan. Griffin, (1998:259)

\section{Teori $\mathrm{X}$ dan $\mathrm{Y}$}

Teori ini dikemukakan oleh Douglas McGregor. Ia membedakan 2 tipe pekerja yaitu $\mathrm{X}$ dan $\mathrm{Y}$. 1) Teori X, menyatakan bahwa orang-orang sesungguhnya malas dan tidak mau bekerja sama. 2) Teori Y, menyatakan bahwa orang-orang sesungguhnya energik, berorientasi kepada perkembangan, memotivasi diri sendiri, dan tertarik untuk menjadi produktif. Griffin, (1998:260)

\section{Manajemen dan Fungsi Manajemen}

Berdasarkan asal katanya, manajemen berasal dari kata management yang merupakan bentuk dari kata kerja to manage yang bermakna mengurus, mengatur, melaksanakan, dan mengelola, sehingga manajemen adalah pengurusan, pengaturan, pelaksanaan, pengelolaan. Kata sumber daya manusia merujuk pada pengertian manusia 
sebagai sumber daya manusia dapat dijabarkan sebagai pengelolaan manusia sebagai sumber daya.

Ahli manajemen pada awal abad ke dua puluh, Mary Parker Follet, (2003:6) mendefinisikan "manajemen sebagai seni untuk menyelesaikan segala sesuatu melalui orang." Baru baru ini, ahli teori manajemen terkemuka, Peter Drucker (2003:6), menyatakan bahwa "pekerjaan manajer adalah untuk memberikan arahan kepada organisasi, memimpin, dan memutuskan bagaimana harusnya menggunakan sumber daya untuk mencapai tujuan tertentu, Menyelesaikan sesuatu melalui orang dan sumber daya lain, memberikan kepemimpinan, Dan pengarahan merupakan hal yang dilakukan oleh manajer".

Sedangkan arti Manajemen dari buku manajemen management, Richard L daft "(management) adalah pencapaian tujuan organisasi dengan cara yang efektif dan efisien melalui perencanaan, pengorganisasian, pengarahan, dan pengendalian sumber daya organisasi manajemen". Richard L daft (2003: 6)

Terdapat 2 definisi penting di atas yaitu: (1) keempat fungsi, yaitu perencanaan, pengorganisasian, pengerahan, dan pengendalian, serta (2) pencapaian tujuan organisasi dengan cara yang efektif dan efisien. Manajer menggunakan berbagai keterampilan untuk melakukan fungsi ini. Konseptual manajemen, keterampilan manusia, dan teknologi akan dibahas kemudian menunjukkan proses bagaimana manajer menggunakan sumber daya untuk mencapai tujuan organisasi. Setelah memahami fungsi manajemen secara umum, maka selanjutnya akan dijelaskan pengertian Sumber Daya Manusia. Menurut Nitisemito (1992:9), pengertian "manajemen adalah suatu ilmu dan seni untuk mencapai tujuan melalui kegiatan orang lain".

Hal ini berarti manajemen hanya dapat dilaksanakan bila dalam pencapaian tujuan tersebut tidak dilakukan oleh satu orang saja, melainkan melalui pengaturan kegiatan orang lain untuk melaksanakan pekerjaan yang dibutuhkan. Untuk lebih menjelaskan pengertian tentang manajemen sumberdaya manusia, penulis akan menguraikannya dari pendapat beberapa ahli, antara lain :

Menurut Newman dan Hodgetts (1998:4), "Human Resources Management (HRM) is the process by which organizations ensure the effective use of their associates in the pursuit of both organizational and individual goals". "Manajemen sumber daya manusia adalah suatu proses yang dilakukan suatu organisasi atau perusahaan untuk memastikan bahwa sumber daya manusia yang ada digunakan secara efektif dalam usaha mencapai tujuan organisasi atau perusahaan serta tujuan individu.

Selanjutnya Fungsi Manajemen Sumber Daya Manusia adalah, "proses memperoleh, melatih, menilai, dan memberikan kompensasi kepada karyawan, memperhatikan hubungan kerja, kesehatan, keamanan, dan masalah keadilan". Gary Desseler (2003 : 5). Sedangkan Fungsi Manajemen menurut Henry Fayol (2010 :179) bahwa semua: "manajer menjalankan fungsi manajemen, yaitu merencanakan, mengorganisasi, mengoordinasi, dan mengendalikan. Dan biasa juga dengan: perencanaan, pengorganisasian, kepemimpinan dan pengendalian" Henry Fayol 
Tasharruf: Journal Economics and Business of Islam Vol. 4, No. 2 (2019): 92-109

Website: http://journal.iain-manado.ac.id/index.php/TJEBI

ISSN 2528-0325 (online) ISSN 2528-0317 (print)

(2010:179)

Tujuan fungsi manajemen menurut Henry Frayol (2010 : 180) :

1. Fungsi perencanaan, meliputi tugas-tugas menyusun rencana kegiatan ke depan dari suatu organisasi, yang meliputi rencana jangka panjang, menengah, pendek, rencana kegiatan serta menetapkan target yang hendak dicapai.

2. Fungsi pengorganisasian, meliputi tugas-tugas apa yang harus dilakukan, siapa yang melakukan, bagaimana tugas-tugas itu dikelompokkan, siapa melapor kepada siapa, dimana keputusan harus diambil.

3. Fungsi kepemimpinan, karena suatu organisasi terdiri dari orang-orang adalah tugas seorang manajer untuk mengarahkan dan mengoordinasikan orang-orang ini. Saat mereka mengarahkan, memotivasi, memilih saluran komunikasi yang efektif atau memecahkan konflik antar anggota semuanya ini adalah fungsi kepemimpinan seorang manajer.

4. Fungsi pengendalian, setelah tujuan-tujuan ditentukan, rencana di tuangkan, pengaturan struktural digambarkan, dan orang-orang dipekerjakan, dilatih, di motivasi masih ada kemungkinan bahwa ada sesuatu yang keliru untuk memastikan semua urusan berjalan sebagai mana mestinya seorang manajer harus memantau kinerja organisasi”.

Penilaian kinerja sumber daya manusia merupakan tanggung jawab departemen sumber daya manusia dan para manajer. Para manajer menanggung tanggung jawab utama untuk mengevaluasi bawahannya dan departemen sumber daya manusia bertanggung jawab untuk mengembangkan bentuk penilaian kinerja yang efektif dan memastikan bahwa penilaian kinerja tersebut dilakukan oleh seluruh bagian perusahaan.

Dalam hal kompensasi/reward dibutuhkan suatu koordinasi yang baik antara departemen sumber daya manusia dengan para manajer. Para manajer bertanggung jawab dalam hal kenaikan gaji, sedangkan departemen sumber daya manusia bertanggung jawab untuk mengembangkan struktur gaji yang baik. Sistem kompensasi yang memerlukan keseimbangan antara pembayaran dan manfaat yang diberikan kepada tenaga kerja. Pembayaran meliputi gaji, bonus, insentif, dan pembagian keuntungan yang diterima oleh karyawan. Manfaat meliputi asuransi kesehatan, asuransi jiwa, cuti, dan sebagainya. Departemen sumber daya manusia bertanggung jawab untuk memastikan bahwa kompensasi yang diberikan bersifat kompetitif diantara perusahaan yang sejenis, adil, sesuai dengan hukum yang berlaku, dan memberikan motivasi.

Departemen sumber daya manusia bertanggung jawab untuk membantu para manajer menjadi pelatih dan penasehat yang baik bagi bawahannya, menciptakan program pelatihan dan pengembangan yang efektif baik bagi karyawan baru (orientasi) maupun yang sudah ada (pengembangan keterampilan), terlibat dalam program pelatihan dan pengembangan tersebut, memperkirakan kebutuhan perusahaan akan program pelati han dan pengembangan, serta mengevaluasi efektifitas program pelatihan 
Tasharruf: Journal Economics and Business of Islam Vol. 4, No. 2 (2019): 92-109

Website: http://journal.iain-manado.ac.id/index.php/TJEBI

ISSN 2528-0325 (online) ISSN 2528-0317 (print)

dan pengembangan. Tanggung jawab departemen sumber daya manusia dalam hal ini juga menyangkut masalah pemutusan hubungan kerja Tanggung jawab ini membantu restrukturisasi perusahaan dan memberikan solusi terhadap konflik yang terjadi dalam perusahaan.

Selain itu para manajer di perusahaan berhubungan erat dengan para karyawan/pekerjanya. Hubungan erat tersebut banyak macamnya, diantaranya kekerabatan, menjalankan kerja sama, pencapaian visi \& misi perusahaan secara bersama-sama, dsb. Dalam kaitannya berhubungan dengan motivasi yang dibutuhkan karyawan yang akan dengan sendirinya mempengaruhi pekerjaan karyawan itu sendiri. Merupakan tugas yang berat para pemimpin untuk memberikan motivasi khusus kepada karyawannya sehingga bisa menghasilkan kinerja yang maksimal.

\section{Produktivitas Kerja}

Produktivitas kerja merupakan perilaku yang ditampakkan oleh individu atau kelompok, yang menurut Siagian (1985 :136-137), dikatakan bahwa "Ditinjau dari segi keperilakuan, kepribadian seseorang sering menempatkan dirinya dalam berbagai bentuk sikap, cara berfikir dan cara bertindak berbagai hal yang mempengaruhi kepribadian seseorang/organisasional yang tercermin dalam perilakunya yang pada gilirannya akan berpengaruh pada kinerjanya.

Konsep produktivitas kerja dapat dilihat dari dua dimensi, yaitu dimensi individu dan dimensi organisasi. Dimensi individu melihat produktivitas dalam kaitannya dengan karakteristik-karakteristik kepribadian individu yang muncul dalam bentuk sikap mental dan mengandung makna keinginan dan upaya individu yang selalu berusaha untuk meningkatkan kualitas kehidupannya. Sedangkan dimensi keorganisasian melihat produktivitas dalam kerangka hubungan teknis antara masukan (input) dan keluaran (out put). Oleh karena itu dalam pandangan ini, terjadinya peningkatan produktivitas tidak hanya dilihat dari aspek kuantitas, tetapi juga dapat dilihat dari aspek kualitas.

Menurut Sugeng Budiono (2003:201) produktivitas mempunyai beberapa pengertian yaitu:

1. Pengertian Phisiologi Produktivitas yaitu sikap mental yang selalu mempunyai pandangan bahwa mutu kehidupan hari ini harus lebih baik dari kemarin, esok harus lebih baik dari hari ini. Pengertian ini mempunyai makna bahwa dalam perusahaan atau pabrik, manajemen harus terus menerus melakukan perbaikan proses produksi, sistem kerja, lingkungan kerja dan lain- lain.

2. Produktivitas merupakan perbandingan antara keluaran (output) dan masukan(input ).Perumusan ini berlaku untuk perusahaan, industri dan ekonomi keseluruhannya. Secara sederhana produktivitas adalah perbandingan secara ilmu hitung, antara jumlah yang dihasilkan dan jumlah setiap sumber daya yang dipergunakan selama proses berlangsung. Sugeng Budiono (2003:201)

Menurut Komarudin, "produktivitas pada hakekatnya meliputi sikap yang 
Tasharruf: Journal Economics and Business of Islam Vol. 4, No. 2 (2019): 92-109

Website: http://journal.iain-manado.ac.id/index.php/TJEBI

ISSN 2528-0325 (online) ISSN 2528-0317 (print)

senantiasa mempunyai pandangan bahwa metode kerja hari ini harus lebih baik dari metode kerja kemarin dan hasil yang dapat diraih esok harus lebih banyak atau lebih bermutu daripada hasil yang diraih hari ini" Komarudin,(1992:121). Setelah membahas tentang definisi dari produktivitas serta beberapa pendapat dari para ahli, selanjutnya akan dijelaskan Faktor-faktor yang mempengaruhi Produktivitas menurut para ahli.

\section{Faktor-Faktor Produktivitas Dan Pengukuran Produktivitas}

Banyaknya faktor yang mempengaruhi produktivitas kerja, baik yang berhubungan tenaga kerja maupun yang berhubungan dengan lingkungan perusahaan dan kebijaksanaan pemerintah secara keseluruhan. Menurut balai pengembangan produktivitas daerah yang dikutip oleh Soedarmayanti bahwa ada enam faktor utama yang menentukan produktivitas tenaga kerja, adalah:

1. Sikap kerja, seperti: kesediaan untuk bekerja secara bergiliran (shift work) dapat menerima tambahan tugas dan bekerja dalam suatu tim.

2. Tingkat keterampilan yang ditentukan oleh pendidikan latihan dalam manajemen supervise serta keterampilan dalam tehnik industri.

3. Hubungan tenaga kerja dan pimpinan organisasi yang tercermin dalam usaha bersama antara pimpinan organisasi dan tenaga kerja untuk meningkatkan produktivitas melalui lingkaran pengawasan mutu (Quality control circles).

4. Manajemen produktivitas, yaitu: manajemen yang efisien mengenai sumber dan sistem kerja untuk mencapai peningkatan produktivitas.

5. Efisiensi tenaga kerja, seperti: perencanaan tenaga kerja dan tambahan tugas.

6. Kewiraswastaan, yang tercermin dalam pengambilan resiko, kreativitas dalam berusaha, dan berada dalam jalur yang benar dalam berusaha'

\section{Hubungan Motivasi dengan Produktivitas Kerja}

Menurut Sondang P. Siagian (1985:128), menguraikan bahwa keseluruhan proses pemberian motivasi kepada para bawahan sedemikian rupa, sehingga mereka mau bekerja dengan ikhlas demi tercapainya tujuan organisasi dengan efektif dan efisien. Dalam bukunya Evaluasi Kinerja SDM situasi kerja yang dapat mempengaruhi motivasi kerja adalah kebijakan perusahaan seperti skala upah dan tunjangan pegawai (Cuff, pensiun dan tunjangan-tunjangan), umumnya mempunyai dampak kecil terhadap prestasi individu (Mangkunegaran:2006). Sistem balas jasa atau imbalan, kenaikan gaji, bonus dan promosi dapat menjadi motivator yang kuat bagi prestasi seseorang jika dikelola secara efektif. Upah harus dikaitkan dengan peningkatan produktivitas sehingga mengapa upah tersebut diberikan, dan upah harus dilihat sebagai sesuatu yang adil oleh orang-orang lain dalam kelompok kerja. Untuk mendorong produktivitas kerja yang lebih tinggi, banyak perusahaan yang menganut sistem insentif sebagai bagian dari 
Tasharruf: Journal Economics and Business of Islam Vol. 4, No. 2 (2019): 92-109

Website: http://journal.iain-manado.ac.id/index.php/TJEBI

ISSN 2528-0325 (online) ISSN 2528-0317 (print)

sistem yang berlaku bagi karyawan perusahaan, salah satu bentuk insentif tersebut adalah pemberian bonus.

\section{METODE PENELITIAN}

\section{Rancangan Penelitian}

Jenis penelitian ini menggunakan observasional analitik dengan rancangan Cross Sectional, yaitu untuk mengetahui hubungan antara variabel motivasi kerja dengan produktivitas kerja. Dengan penelitian ini maka dapat dibangun suatu teori yang dapat berfungsi untuk menjelaskan, meramal, memprediksi dan mengontrol suatu gejala. Penelitian ini bersifat kuantitatif karena menggunakan data yang memerlukan perhitungan dan menggunakan analisa kualitatif untuk mendiskripsikan data-data yang sudah diperoleh sehingga akan lebih jelas data tersebut. Pada penelitian ini terdapat dua variabel yang berhubungan, yaitu variabel X (Motivasi) dan variabel Y (Produktivitas Kerja).

Untuk melihat adanya pengaruh motivasi terhadap kinerja karyawan digunakan analisis regresi berganda. Analisis regresi berganda tersebut bertujuan untuk melihat ada tidaknya pengaruh yang signifikan antara motivasi terhadap produktivitas kinerja karyawan pada PT. TELKOM. Untuk menganalisis data ke dalam regresi sederhana tersebut digunakan software SPSS. Hasil dari olah data inilah yang akan diinterkinerjakan dalam pembahasan hasil. "Model analisis regresi sederhana digunakan untuk melihat pengaruh motivasi terhadap produktivitas kinerja karyawan, yang dikutip dalam buku Walpole (1995 : 342)” dengan rumus sebagai berikut :

$\mathrm{Y}=\mathrm{a}+\mathrm{b}_{1} \mathrm{X}_{1}+\mathrm{b}_{2} \mathrm{X}_{2}+\mathrm{e}$

Dimana :

$\mathrm{Y} \quad=$ Kinerja PT. Telkom (Produktivitas Kerja)

a $\quad=$ Kostanta

$\mathrm{X}_{1} \quad=$ Motivasi Eksternal

$\mathrm{X}_{2} \quad=$ Motivasi Internal

$\mathrm{b}_{1}, \mathrm{~b}_{2}=$ Koefisien regresi

e $\quad=$ Standar error

Untuk mengetahui besarnya pengaruh antara motivasi terhadap kinerja karyawan digunakan rumus koefisien korelasi (r) yang dikutip dalam buku walpole (1995 : 371) sebagai berikut :

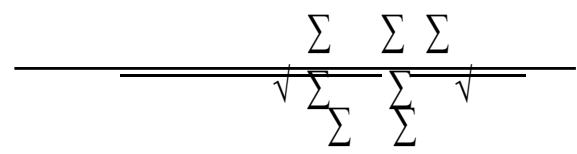

Instrumen penelitian (kuesioner) yang baik harus memenuhi persyaratan yaitu valid dan reliabel. Untuk mengetahui validitas dan reliabilitas kuesioner perlu dilakukan 
Tasharruf: Journal Economics and Business of Islam Vol. 4, No. 2 (2019): 92-109

Website: http://journal.iain-manado.ac.id/index.php/TJEBI

ISSN 2528-0325 (online) ISSN 2528-0317 (print)

pengujian atas kuesioner dengan menggunakan uji validitas dan uji reliabilitas.

a. Uji reliabilitas dimaksudkan untuk mengukur suatu kuesioner yang merupakan indikator dari variabel. Reabilitas diukur dengan uji statistik cronbach's alpha $(\alpha)$. Suatu variabel dikatakan reliabel jika memberikan nilai cronbach' alpha $>0,60$ (Imam Ghozali, 2007)

b. Uji validitas digunakan untuk mengukur sah atau valid tidaknya suatu kuesioner. Uji validitas dilakukan dengan melakukan korelasi bivariate antara masing-masing skor indikator dengan total skor variabel.

\section{HASIL DAN PEMBAHASAN}

Penelitian ini menguraikan mengenai pengaruh motivasi terhadap produktivitas kerja karyawan pada PT. Telekomunikasi Indonesia. Hal ini bertujuan untuk mengetahui seberapa besar pengaruh motivasi eksternal/internal dalam meningkatkan produktivitas kerja karyawan pada PT. Telekomunikasi Indonesia. Dalam penelitian ini, diambil sebanyak 54 karyawan sebagai sampel penelitian.

Karakteristik responden yaitu menguraikan deskripsi identitas responden menurut sampel penelitian yang telah ditetapkan. Salah satu tujuan dengan deskripsi karakteristik responden adalah memberikan gambaran yang menjadi sampel dalam penelitian ini.

Dalam penelitian sampel, karakteristik responden dikelompokkan menurut umur, jenis kelamin dan unit kerja. Oleh karena itulah uraian mengenai karakteristik responden dapat diuraikan sebagai berikut

1. Karakteristik responden berdasarkan umur

Adapun karakteristik responden berdasarkan umur dapat dilihat melalui tabel 1 berikut ini

Tabel 1. Karakteristik Responden Menurut Umur

\begin{tabular}{|l|c|c|}
\hline \multirow{2}{*}{ Usia } & \multicolumn{2}{|c|}{ Tanggapan responden } \\
\cline { 2 - 3 } & Orang & $\%$ \\
\hline $21-30$ & 9 & 17 \\
\hline $31-40$ & 11 & 20 \\
\hline $41-50$ & 27 & 50 \\
\hline Di atas 50 & 7 & 13 \\
\hline & 54 & 100 \\
\hline
\end{tabular}

Sumber : Data diolah, Kuesioner 
Tasharruf: Journal Economics and Business of Islam Vol. 4, No. 2 (2019): 92-109 Website: http://journal.iain-manado.ac.id/index.php/TJEBI ISSN 2528-0325 (online) ISSN 2528-0317 (print)

Berdasarkan hasil olahan data mengenai karakteristik responden yang berdasarkan umur, maka jumlah responden terbesar adalah responden yang berumur antara 41 - 50 tahun yakni sebesar $50 \%$. Sehingga dapat dikatakan bahwa rata-rata pegawai/karyawan PT. Telkom berumur $41-50$ tahun.

Tabel 2. Tanggapan Responden Menurut Usia

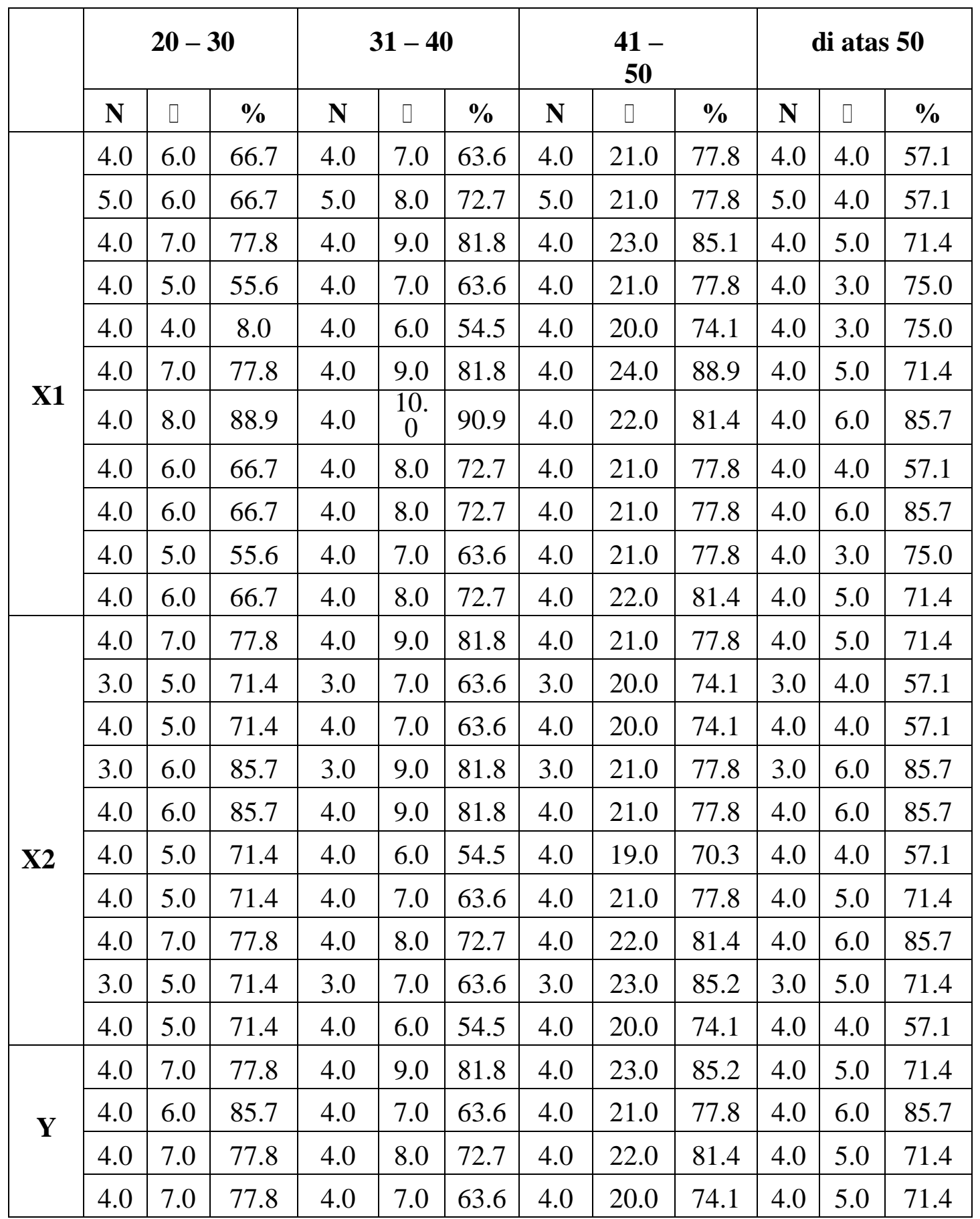

Sumber: Data diolah, Kuesioner 
Berdasarkan hasil olahan data di atas mengenai tanggapan responden menurut usia pada kuesioner Motivasi Eksternal. Responden berusia 20-30 tahun, 7 orang menjawab setuju dengan persentase sebesar $78 \%$ dari total 9 orang responden. Responden yang berumur 31-40 tahun rata-rata menjawab setuju, yakni sebanyak 8orang dengan persentase sebesar 72\% dari total 11 responden. Untuk usia 41-50 tahun menjawab setuju, yakni sebanyak 15 orang dengan rata-rata persentase sebanyak diatas 56\% dari total 27 responden. Sedangkan responden yang berumur di atas 51 tahun menjawab setuju, yakni sebanyak 7 orang dengan persentase sebanyak $100 \%$ dari total 7 responden.

Selanjutnya tanggapan responden pada kuesioner Motivasi Internal sebagian besar responden berusia 20-30 tahun menjawab setuju yakni sebanyak 4 orang dengan persentase $44 \%$ dari total 9 responden. Sedangkan sebagian besar responden yang berumur 31-40 tahun menjawab setuju, yakni sebanyak 5orang dengan persentase $45 \%$ dari total 11responden. Untuk usia 41-50 tahun menjawab setuju, yakni sebanyak 11 orang dengan persentase sebanyak $41 \%$ dari total 27 responden. Sedangkan responden yang berumur di atas 51tahun menjawab setuju, yakni sebanyak 5orang dengan persentase di atas $71 \%$ dari total 7 responden.

Selanjutnya tanggapan responden pada kuesioner Produktivitas Kinerja sebagian besar responden berusia 20-30 tahun menjawab setuju yakni sebanyak 3 orang dengan persentase $33 \%$ dari total 9 responden. Sedangkan sebagian besar responden yang berumur 31-40 tahun menjawab setuju, yakni sebanyak 3 orang dengan persentase di bawah 28\% dari total 11 responden. Untuk usia 41-50 tahun menjawab setuju, yakni sebanyak 7 orang dengan persentase sebanyak $26 \%$ dari total 27 responden. Sedangkan responden yang berumur di atas 51 tahun menjawab setuju, yakni sebanyak 3 orang persentase $43 \%$ dari total 7 responden.

Berdasarkan tanggapan responden mengenai motivasi eksternal dalam upaya meningkatkan produktivitas kerja karyawan dengan berbagai pertanyaan pemahaman pegawai/karyawan tentang kinerja, gaji, tunjangan dalam perusahaan dan tantangan dalam bekerja, maka dari 54 pegawai/karyawan yang telah memberikan tanggapan dalam kuesioner dapat kita lihat dengan table di bawah ini. Dengan melihat Rata-Rata Persentase 1) $85-100 \%=$ Sangat Baik; 2) $65-84 \%=$ Cukup; 3). $<65 \%=$ Kurang

Selanjutnya, tanggapan responden mengenai pemberian penghargaan bagi karyawan yang berprestasi akan meningkatkan motivasi kerja karyawan, rata-rata responden memberikan jawaban setuju, yakni $62 \%$. Tanggapan selanjutnya mengenai upah/gaji yang diberikan sesuai dengan pekerjaan saya, rata-rata responden memberikan jawaban setuju, yakni $74 \%$. Selanjutnya mengenai atasan memberikan pelatihan kepada karyawan, dengan rata-rata responden memberikan jawaban setuju, yakni $82 \%$.

Sementara itu, tanggapan responden mengenai atasan selalu mengkomunikasikan dengan bawahan segala sesuatu yang berhubungan dengan pencapaian tugas, rata-rata responden menjawab setuju, yakni $66 \%$. Selanjutnya mengenai atasan selalu memberikan pujian kepada karyawan yang menyelesaikan tugasnya dengan baik, rata-rata responden menjawab setuju, yakni $68 \%$. Kemudian 
Tasharruf: Journal Economics and Business of Islam Vol. 4, No. 2 (2019): 92-109

Website: http://journal.iain-manado.ac.id/index.php/TJEBI

ISSN 2528-0325 (online) ISSN 2528-0317 (print)

tanggapan responden mengenai situasi lingkungan kerja baik dan menyenangkan, ratarata karyawan menjawab setuju, yakni $64 \%$.

Selanjutnya, tanggapan responden mengenai bekerja disini membuat karyawan berkembang kemampuannya, rata-rata responden menjawab sedang, yakni $72 \%$. Kemudian tanggapan responden mengenai pekerjaan yang saya kerjakan menarik untuk diselesaikan, rata-rata karyawan menjawab setuju, yakni $72 \%$. Untuk tanggapan responden mengenai support keluarga menjadi semangat kerja, rata-rata karyawan menjawab setuju, yakni sebesar 54\%. Selanjutnya tanggapan responden mengenai bekerja disini karyawan mendapatkan kesempatan mempelajari hal-hal baru, rata-rata karyawan menjawab setuju, yakni $64 \%$.

Dari hasil penelitian di atas dapat dilihat pengaruh motivasi eksternal terhadap produktivitas kerja sangat tinggi dibanding motivasi internal. Hubungan motivasi eksternal terhadap produktivitas kerja sangat mempengaruhi peningkatan kerja karyawan sebanyak $52.2 \%$. Dalam penelitian ini motivasi eksternal yang paling mempengaruhi produktivitas kerja karyawan adalah komunikasi yang baik antara karyawan dan atasan, lingkungan kerja yang baik, dan atasan selalu memberikan pujian. Tiga factor utama itu yang dapat meningkatkan kinerja karyawan dalam menyelesaikan tugas. Sedangkan dari tanggapan responden hubungan motivasi internal terhadap produktivitas kerja karyawan rata-rata $32.2 \%$. Dalam penelitian ini tiga factor utama dari motivasi internal yang memberikan pengaruh terhadap produktivitas kerja adalah prestasi kerja yang dimiliki, kepuasan dalam menyelesaikan tugas, dan pekerjaan yang menarik.

Berdasarkan hasil uji regresi linier didapatkan nilai unstandarized coefficient $B$ dari motivasi eksternal 0,522, lebih besar dibanding motivasi eksternal sebesar 0,322. Artinya bahwa 52,2\% kinerja karyawan dipengaruhi oleh motivasi eksternal. Dari hasil penelitian ini bisa disimpulkan bahwa Motivasi Eksternal lebih dominan dalam meningkatkan produktivitas kerja karyawan. Indicator dari motivasi eksternal tersebut antara lain atasan yang baik, Kondisi Kerja dan Jaminan Financial \& Social. Dalam penelitian ini factor gaji tidak membuat seorang karyawan termotivasi dengan produktivitas kerja dikarenakan kebutuhan fisiologis mereka sudah terpenuhi.

\section{KESIMPULAN}

Berdasarkan hasil analisis dan pembahasan, maka kesimpulan yang dapat diambil adalah sebagai berikut:

1. Motivasi Eksternal dalam perusahaan PT. Telkom memiliki pengaruh signifikan terhadap produktivitas kinerja berdasarkan persepsi karyawan.

2. Dari hasil analisis, diperoleh hasil bahwa motivasi eksternal (Kondisi Kerja, Atasan yang Baik, Jaminan Financial dan Sosial) memberikan pengaruh terhadap produktivitas kinerja perusahaan. Sedangkan analisis yang diperoleh dari motivasi internal (Pekerjaan yang Menyenangkan, Pekerjaan yang Menantang, dan Pekerjaan yang Menarik) memberikan pengaruh terhadap produktivitas. Dengan demikian, 
Tasharruf: Journal Economics and Business of Islam Vol. 4, No. 2 (2019): 92-109

Website: http://journal.iain-manado.ac.id/index.php/TJEBI

ISSN 2528-0325 (online) ISSN 2528-0317 (print)

hipotesis yang diajukan terbukti.

3. Motivasi eksternal dan internal berpengaruh secara simultan terhadap kinerja karyawan. Hal ini dibuktikan dengan uji koefisien determinasi, yakni sebesar $47 \%$ kinerja karyawan dipengaruhi oleh variasi kedua variabel yang digunakan dalam penelitian, sisanya 53\% dipengaruhi oleh faktor lain.

4. Motivasi eksternal lebih dominan berpengaruh terhadap kinerja karyawan. Hal ini dibuktikan dengan koefisien regresi motivasi eksternal lebih besar dibanding motivasi internal.

5. Motivasi eksternal yang paling dominan mempengaruhi produktivitas adalah komunikasi yang baik antara karyawan dan atasan/sedangkan motivasi internal adalah prestasi kerja yang dimiliki, berdasarkan dari penelitian yang dilakukan.

\section{DAFTAR PUSTAKA}

Algifari. 1997. Analisis Statistik Untuk Bisnis; Dengan Regresi, Korelasi dan Nonparametrik. Yogyakarta: BPFE.

Chandradewi, Ayuningtyas. 2008. Faktor yang mempengaruhi produktivitas kerja.http://www.scribd.com/doc/56524013/15/faktor-yangmempengaruhiproduktivitas-kerja

Dearden Bedford, Anthony. 1985. Sistem Pengendalian Manajemen Edisi 5.Bandung: Erlangga.

Eka Suhartini, 2013 Motivasi, Kepuasan Kerja Dan Kinerja, Alauddin University Press

Gary, Dessler. 2003. Manajemen SDM. Jakarta : Indeks

H. Hadari, Nawawi. 2000. Management strategic organisasi non profit bidang Pemerintahan. Dalam William. dan Davis. 2003(Ed.), perbedaan motivasi eksternal dan internal. Yogya penerbit: UGM

Hasibuan.Malayu.SP; 2007.Organisasi dan Motivasia Jakarta: Bumi Aksara

Ishak dan Hendri Tanjung, Ishak dan Hendri Tanjung; 2003.Manajemen Motivasi. Jakarta. PT. Grasindo

Jsupranto. 1984. Ekonometrik. Jakarta : Lembaga Penerbit FE-UI

Malayu S.P. Hasibuan, 2000, Manajemen Sumber Daya Manuisa, Yogyakarta, Liberty Mangkunegara, Anwar Prabu,2006, Evaluasi Kinerja Sumber Daya Manusia, Edisi Kedua, Bandung PT Refika Aditama. 
Tasharruf: Journal Economics and Business of Islam Vol. 4, No. 2 (2019): 92-109 Website: http://journal.iain-manado.ac.id/index.php/TJEBI ISSN 2528-0325 (online) ISSN 2528-0317 (print)

Maulana, Sulastiana. 2009. Kepemimpinan melalui Motivasi Karyawan. (http://pustaka.unpad.ac.id/wpcontent/uploads/2009/12/kepemimpinan_me lalui_motivasi.pdf, diakses 20 Sept. 2012)

Robbins. Stephen. P; 2008.Perilaku Organisasi. PT. Indeks Kelompok Gramedia

Tabe, Ridwan. "The Influence On The Effectiveness Of Rolling Employees Work In Manado State Islamic Institute (IAIN)." Tasharruf: Journal Economics and Business of Islam 1, no. 2 (2017).

Tabe, Ridwan. "Analisis Perhitungan Pegadaian Umum Dan Pegadaian Syariah Dalam Konteks Gadai Emas." Tasharruf: Journal Economics and Business of Islam 1, no. 1 (2017).

Tabe, Ridwan. "The Effect of Premium on Profit of Life Insurance Companies in Sharia Units of Pt Panin Dai-Ichi Life Indonesia." Tasharruf: Journal Economics and Business of Islam 3, no. 2 (2019).

Saleh, Setiawan, and Ridwan Tabe. "Analysis Of Stock Price At Pt. Telkom Indonesia Tbk Before And After Having Damage On Its Satelit." Tasharruf: Journal Economics and Business of Islam 3, no. 1 (2018).

Veithzal Rivai dan Ella Jauvani Sagala, 2016. Manajemen Sumber Daya Manusia untuk Perusahaan.

Winardi.P. 2002; Motivasi dan Pemotivasian dalam Manajemen. Cetakan kedua Jakarta: PT. Raja Grafindo Persada. 